(C) 1983 ISIJ

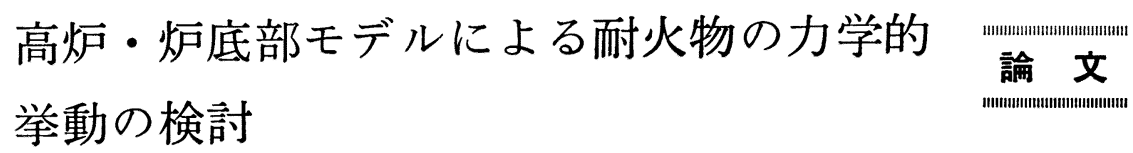

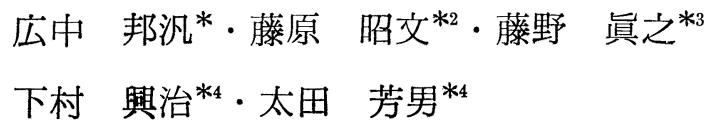

\title{
Experimental Study on the Mechanical Behavior of Refractories by a Blast Furnace Hearth Model
}

Kunihiro Hironaka, Akibumi FujIwara, Masayuki Fujino, Koji Shimomura, and Yoshio OHta

Synopsis :

To study the fracture mechanism of the refractories of blast furnace by thermal stress, a model furnace of hearth and bottom of Kakogawa No. 2 B. F. was constructed. The model furnace was heated to about $1500^{\circ} \mathrm{C}$, twice.

Thermal stress(strain), displacement of refractories and those of shell were measured during the heating test. Grack behaviour of the refractories was detected by A. E. during the heating test and also by visual inspection after the test.

The results are summarized as follows:

1. High stress was observed in refractories and in shell at the first heating test. The stress observed at the second heating test was less than that of the first. Also, displacement of shell and refractories was fairly affected by heat hysterisis. These phenomena may be caused mainly by irreversible shrinkage of joint mortal and carbon stamp.

2. Cracks were detected at side face of carbon blocks, by visual inspection. The result of A. E. signal indicated that these cracks probably occurred at the final stage of heating process of the first heating test.

\section{1. 緒}

言

高炉の寿命延長を計るためには, 炉底部や湯溜り部に 拈ける耐火物の局部侵食や, シャフト下部から炉腹部に かけての耐火物の脱落などを防止することが重要であ る1). これら耐火物の損傷原因として，溶銑やアルカリ など化学的な侵食作用のほかに, 温度変動時に発生する 熱応力による損傷も重要視され, 近年, 耐火物の力学面 に関する研究が多く実施されている.たとえば，れんが の熱衝撃割れ特性を定量的に明らかにした熊谷ら2) や加 藤ら ${ }^{3)}$ の数值解析的研究, あるいはシャフト部耐火物の 損傷機構に関する飯山ら 4 ) や熊谷ら5)の実験的研究など があげられる。

しかし，これらの研究の多くは主にれんが単体に生ず る内部の引張応力を対象にしたものであり, 目地モルタ ル（以下目地と略す）や，鉄皮なども含めた耐火物構造
体としての圧縮熱応力下での割れの発生機構を対象とし たものは見受けられない.とくに，目地やスタンプは， れんがの熱膨張に対する吸収代として, 耐火物構造体に とつて重要な影響を及ぼすことが予想され，例えば平櫛 らによつて目地材の力学特性, 耐火物構造体としての変 形特性等に関して一連の研究(6) 8) がなされているが, 耐 火物の割れの論議にまでは到つていないようである.

そこで, 構造体としての耐火物の熱応力発生現象を実 際に把握し，また熱応力による破壊機構を検討するため に，高炉の炉底部を模したモデル実験炉（以下モデル炉 と略す）を, 築造して, 高炉火入れ時を想定した昇温実 験を行い, 目地, スタンプ, 鉄皮などの境界構成物存在 下でのカーボンブロックの熱応力, 変形挙動, および湯 溜り部カーボンブロックに発生する割れ形態と炉底シャ モットれんがの割れ形態等を明らかにした.

昭和 57 年 4 月本会講演大会にて発表 昭和 57 年 8 月 2 日受付 (Received Aug. 2, 1982)

* (株) 神戸製鋼所構造研究所 (現：(株) 神戸製鋼所貯槽システム室) (Structural Engineering Laboratory, Now Storage Tank Engineering Dept., Kobe Steel, Ltd.)

*2 (株) 神戸製鋼所構造研究所 (Structural Engineering Laboratory, Kobe Steel, Ltd.)

*3 (株) 神戸製鋼所構造研究所 工博 (Structural Engineering Laboratory, Kobe Steel, Ltd., 6-32 Doi-cho Amagasaki 660)

*4 (株) 神戸製鋼所加古川製鉄所 (Kakogawa Works, Kobe Steel, Ltd.) 


\section{2. モデル炉の仕様および実験方法}

モデル炉は，Fig. 1 に示すように，加古川第 2 高炉 (1 次)の羽口部より下の炉底構造に類似させて, 湯溜り 部にカーボンブロックを, 炬底部では上部にシャモット れんが，下部にカーボンブロックを配置した。 それぞれ のれんがの物性值，化学成分を Table 1 に示す.

モデル炉の形状寸法は実炉の約 $1 / 4$ であるが，策炉 上の制約から，れんが単体の大きさは実炉のそれの $1 / 2$ 程度として，炉体に比べて大きなものを用いた．同様に 目地厚みも，カーボンブロック間では実炉の $1 / 2$ の 0.3 $\mathrm{mm}$ を, シャモットれんが間では実炉と同一の $2 \mathrm{~mm}$ 標準にした。 また，シャモットれんが・カーボンブロッ ク間およびカーボンブロック・鉄皮間のスタンプ厚みは

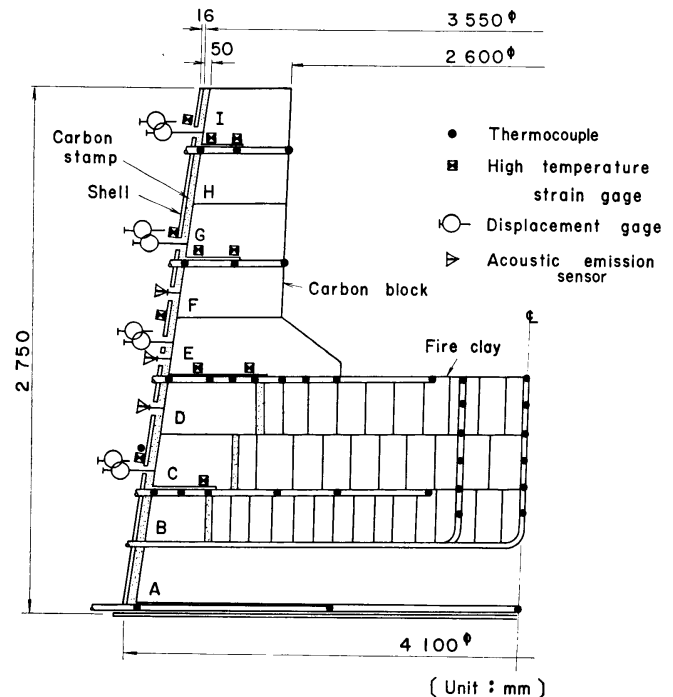

Fig. 1. Construction of the experimental blast furnace hearth and the location of sensors.

Table 1. Properties of refractories in model furnace.

\begin{tabular}{|c|c|c|c|}
\hline & & Carbon block & Fire clay \\
\hline Porosity (\%) & & 18 & 12 \\
\hline Specific gravity & & 1.6 & 2.3 \\
\hline Thermal expansion (\%) & $\begin{array}{l}\text { at } 500^{\circ} \mathrm{C} \\
\text { at } 1000^{\circ} \mathrm{C}\end{array}$ & $\begin{array}{l}0.15 \\
0.30\end{array}$ & $\begin{array}{l}0.35 \\
0.62\end{array}$ \\
\hline $\begin{array}{r}\text { Compressive strength* } \\
\qquad\left(\mathrm{kgf} / \mathrm{mm}^{2}\right)\end{array}$ & $\begin{array}{l}\text { at } \mathrm{R} . \mathrm{T} \text {. } \\
\text { at } 500^{\circ} \mathrm{C} \\
\text { at } 1000^{\circ} \mathrm{C}\end{array}$ & $\begin{array}{l}4.2 \\
4.5 \\
5.0\end{array}$ & $\begin{array}{r}5.3 \\
6.2 \\
11.0\end{array}$ \\
\hline $\begin{array}{l}\text { Bending strength* } \\
\qquad\left(\mathrm{kgf} / \mathrm{mm}^{2}\right)\end{array}$ & $\begin{array}{l}\text { at } \mathrm{R} . \mathrm{T} \text {. } \\
\text { at } 500^{\circ} \mathrm{C} \\
\text { at } 1000^{\circ} \mathrm{C}\end{array}$ & $\begin{array}{l}1.5 \\
1.7 \\
1.8\end{array}$ & $\begin{array}{l}1.2 \\
1.5 \\
2.2\end{array}$ \\
\hline $\begin{array}{l}\text { Chemical composition } \\
\text { (wt } \%)\end{array}$ & & C 96 & $\begin{array}{l}\mathrm{Al}_{2} \mathrm{O}_{3} 44 \\
\mathrm{SiO}_{2} 55 \\
\mathrm{Fe}_{2} \mathrm{O}_{3} 1\end{array}$ \\
\hline
\end{tabular}

*Specimens were loaded in direction of extrusion.
実炉の $1 / 2$ として，それぞれ $25 \mathrm{~mm}, 50 \mathrm{~mm}$ を標準に 施工した.

モデル炉の温度，応力および変位などの測定のために Fig. 1 に示す位置に, 各種の計測センサーを設置し た。

温度計測に関しては, れんがの稼動面, 背面および中 央付近の各点, 扝よび鉄皮外表面に， $\mathrm{R}$ 型および $\mathrm{K}$ 型熱 電対を設置して，その熱起電力値から各点の温度を求め た.

れんがの熱応力測定のために, 湯溜り部カーボンブロ ックの下面に，高温ひずみグージ（約 $600^{\circ} \mathrm{C}$ まで測定 可能）をセラミック溶射法により貼り付けた. 同様に鉄 皮外面にも, 高温用䇴ひずみゲージ（約 $350^{\circ} \mathrm{C}$ まで測定 可能）をシリコン樹脂で接着した. なお，高温ひずみゲ ージは温度上昇に伴つて見かけひずみを生ずるため9), これを測定值から差し引き補正する必要がある.このた め, モデル炉実験前にあらかじめ, 各ひずみゲージの温 度・ひずみ特性曲線を求めておいた。

れんがおよび鉄皮の半径方向の変位を測定するため に，炉外周部にひずみ変換式変位計を各点 2 個ずつ設置 した.これにより，同一箇所におけるカーボンブロック と鉄皮の相対変位が求められるよらにした.

さらに，れんがの割れ発生を検知するために，D， E， $\mathrm{F}$ 段のカーボンブロックに $\mathrm{AE}$ (Acoustic Emission) 検 出器を, ウェーブガイドを介して取り付けた。

モデル炉の加熱方法は， 3 相電極によるアーク加熱と し，さらに，炉内面全面が均一に昇温するようにューク スなどを炉床面に敷設した。 また，カーボンブロックの 酸化を防止するために，常時，窒素ガスを炉内に充満さ せた。

鉄皮の冷却方法は，高炉炉底部と同様に，側壁面で全 周を散水し，炉底面でパイプ流水とした。

なお，本試験の前に，れんが，目地およびスタンプの 乾燥のために, 炉内温度 $400^{\circ} \mathrm{C}$ 程度の予備昇温を行つ た.

\section{3. 昇降温による炉体の応力および変形}

Fig. 2〜4 は, 炉体各点の温度, 変形および応力の各 測定值の経時変化を示すものである.

Fig. 2 のように, 試験開始から約 1 日経過した時点 で, 炉内温度が $1500^{\circ} \mathrm{C}$ 近くまで上昇したが，この初 期の昇温曲線は高炉の火入れ直後の温度条件を模擬した ものである, すなわち, 高炉は通常, 火入れの翌日には 初出銑されるが，この状態を想定して，モデル炉の稼動 面を溶銑温度に相当する $1500^{\circ} \mathrm{C}$ 程度まで昇温させた。 


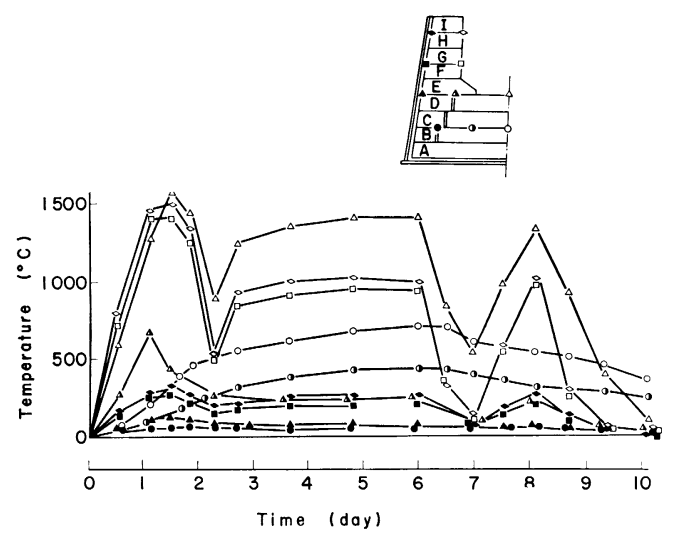

Fig. 2. Temperature transition of refratories.

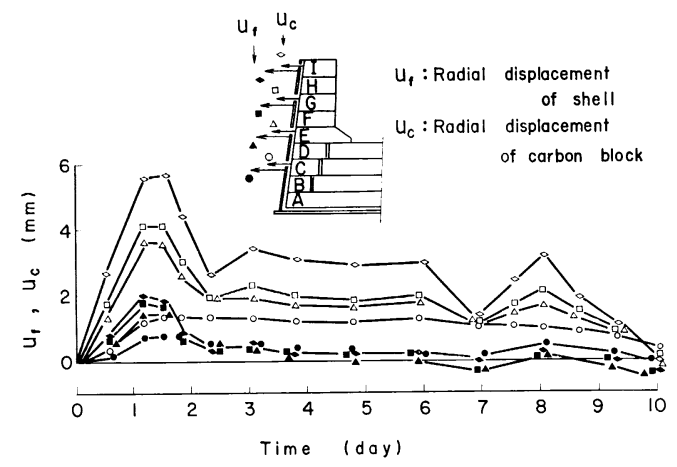

Fig. 3. Transition of radial displacement of shell and carbon blocks.

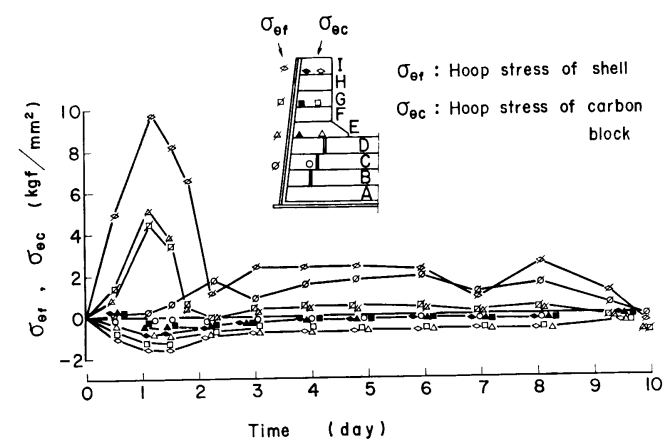

Fig. 4. Transition of hoop stress of shell and carbon blocks.

Fig. 5 は昇温初期の段階において，（a）湯溜り部お よび炉底部カーボンブロックの半径方向, (b)炉底中心 線上シャモットれんがの高さ方向, それぞれの温度分布 を示寸ものである. 稼動面温度は両者ともほぼ同程度に 上昇したが，シャモット部は熱伝導率が低いため, 指数 関数に近い温度分布を示した。 これに対して, 湯溜り部

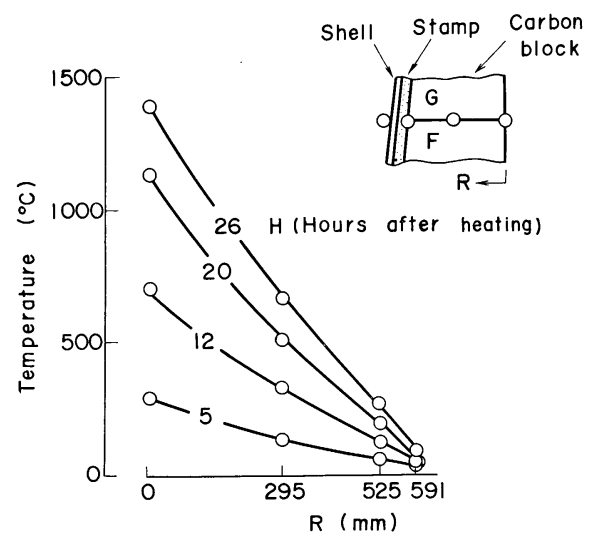

(a) Carbon blocks at ring wall

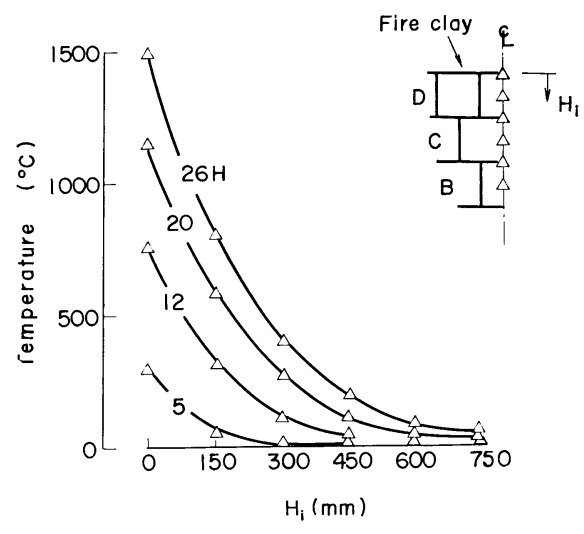

(b) Fire clays at bottom

Fig. 5. Temperature distribution after heating.

カーボンブロックでは昇温時にもかかわらず，その温度 分布はほぼ線形であり, 定常状態のそれに近いことがわ かる.

初期昇温で炉内が最高温度に達したのち, 降温および 昇温を繰り返して，急激な温度変動がれんがや鉄皮の応 力、変形に及ぼす影響を調べた。

Fig. 3 に，カーボンブロックと鉄皮の半径方向変位 を示す. 各段のカーボンブロックの変位は, Fig. 2 に 示す同段の稼動面側での温度変動と良好な対応を示す が, 昇降温の繰り返しによつて変位の変動幅が減少する 傾向にあることがわかる．また，カーボンブロックと鉄 皮の変位差についても同様の傾向が見受けられる.この 両者の変位差から求めたスタンプの収縮率 クの経時変化 例を Fig. 6(a) に示す。 な抏, 同図に示すように, 炉 体冷却後もスタンプでは， $\eta=2 \%$ 程度の圧縮変形が残 留した. Fig. 6 (b) に, 温度分布から逆算して求めた スタンプのみかけの熱伝導率 $\lambda$ の経時変化を示し, さら 

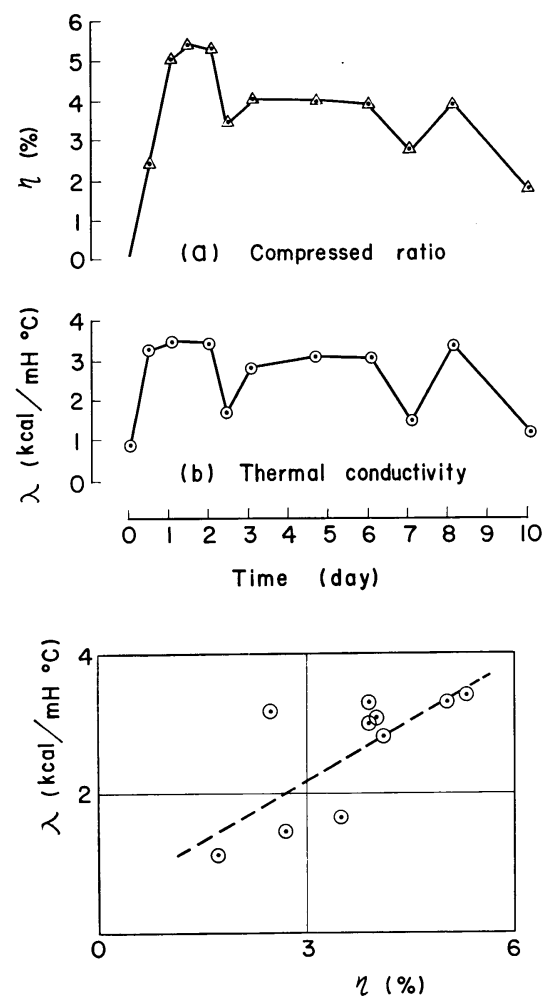

(c) Relation between $\eta$ and $\lambda$

Fig. 6. Transition of the compressed ratio $\eta$ of stamp.

に Fig. 6(c) にクと入の関係を示す. 同図では, ばら つきが認められるが，入はクが大きくなるにつれ増加す る傾向にある.

Fig. 4 に，カーボンブロック持よび鉄皮のそれぞれ の円周方向応力 $\sigma_{\theta \mathrm{c}}, \sigma_{\theta \mathrm{f}}$ の経時変化を示す. 同図からは $\sigma_{\theta \mathrm{f}}$ は引張, $\sigma_{\theta \mathrm{c}}$ は特に稼動面側で大きな圧縮であるこ とがわかる，また，同図に拈ける温度変動と応力変動の 関係は, 前述の温度変動と変位変動の関係と同様な履歴 依存性を示し, Fig. 3 と Fig. 4 の良好な対応が認め られる.

また，Fig. 2 より，E 段より上部の炉体温度は，10 日後には常温に戻つている. 同日，同位置における鉄皮 は, 半径方向に初期の状態よりも収縮していることが Fig. 3 よりわかる. この現象は, スタンプ施工時の初 期圧力が，スタンプ等の不可逆変形に伴つて解放された ことによるものと思われる.

次に, 実験終了後の解体調査の結果では, 隣接カーボ ンブロック間, 鉄皮・スタンプ間, スタンプ・カーボン ブロック間にすき間が確認された。 それらの值は，G段

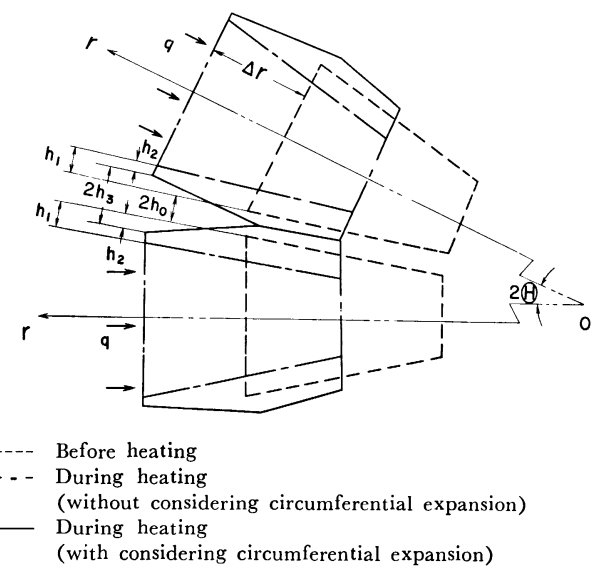

Fig. 7. Distortion and movement of carbon blocks.

の隣接カーボンブロック間では，稼動面側で最大 1.0 $\mathrm{mm}$ ，鉄皮側で最大 $0.4 \mathrm{~mm}$ であつた. スタンプ・鉄 皮間では最大 $1.6 \mathrm{~mm}$ ，スタンプ・カーボンブロック間 では最大 $0.4 \mathrm{~mm}$ であつた. ただし，隣接カーボンブロ ック間の目地は消失している部分が多かつた.

ここで，Fig. 7 を用いて昇温時のカーボンブロック の変形および移動に伴うすき間の挙動を考察する. 昇温 前のカーボンブロックの状態を Fig. 7 の破線とする.

昇温時には, カーボンブロックの熱膨張の一部は目地に よつて吸収されるが，目地の限界吸収量を越えた場合に は，隣接カーボンブロックが互いに押し合ら。この際の 反カとカーボンブロックのせりによつて，カーボンブロ ックは鉄皮側に押される. その状態は Fig. 7 の実線で 示される.

鉄皮側カーボンブロック間隔 $2 h_{3}$ は, カーボンブロッ クの鉄皮側への移動による間隔増大 $2 h_{1}$, 熱膨張による 間隔減少 $2 h_{2}$, および初期の間隔 (目地厚) $2 h_{0}$ により次 式で与えられる.

$$
2 h_{3}=2 h_{0}+2 h_{1}+2 h_{2}
$$

式(1)の $2 h_{0}$ は設計寸法で $0.3 \mathrm{~mm}$ であり, $2 h_{1}, 2 h_{2}$ はとれぞれ次式で与えられる.

$$
\begin{aligned}
& 2 h_{1}=\Delta r \cdot \sin \Theta \ldots \\
& 2 h_{2}=\Delta T \cdot \alpha \cdot B
\end{aligned}
$$

ただし， $\Delta r, \Theta$ およびBは Fig. 7 に示す形状諸元で あり， $\alpha, \Delta T$ はそれぞれカーボンブロックの熱膨張率， 鉄皮側の温度上昇量である.

G段でのこれらの值を式 (1)〜 (3)に代入すれば，力 ーボンブロック間隔 $2 h_{3}$ は $0.89 \mathrm{~mm}$ となる. この值は 初期值 $2 h_{0}=0.3 \mathrm{~mm}$ の 3 倍にもなる. このような変形 抵抗を目地部が持つとは考えられず，したがつてカーボ 
ンブロック鉄皮側では昇温中からすき間が生じていたと 考えられる。

なお，鉄皮・スタンプ間，スタンプ・カーボンブロッ ク間，および隣接カーボンブロック間の稼動面側にもす き間が生じていたことは前述のとおりであるが，スタン プと稼動面側目地部は昇温中は圧縮状態にある. したが つて，これらの部位に拈けるすき間は冷却過程で生じた ものと思われる。また，隣接カーボンブロック間のすき 間は, 実験終了後は, 鉄皮側よりも稼動面側の方が大き かつた. この原因は, 後述するカーボンブロック稼動面 側の圧縮クリープ変形に起因すると思われる.

このように, 耐火物構造体では昇温および降温によつ て, 目地あるいはスタンプにすき間が生ずるため, 圧縮 力のみを伝達する構造体となつていることがわかる.さ らにスタンプ等の不可逆変形のため, この圧縮力も, 火 入れ直後に相当する最初の昇温時のものが最も大きいこ とが明らかになつた。

\section{4. れんがの割れ}

昇温実験終了後, モデル炉を解体し, 炉体の損傷状態
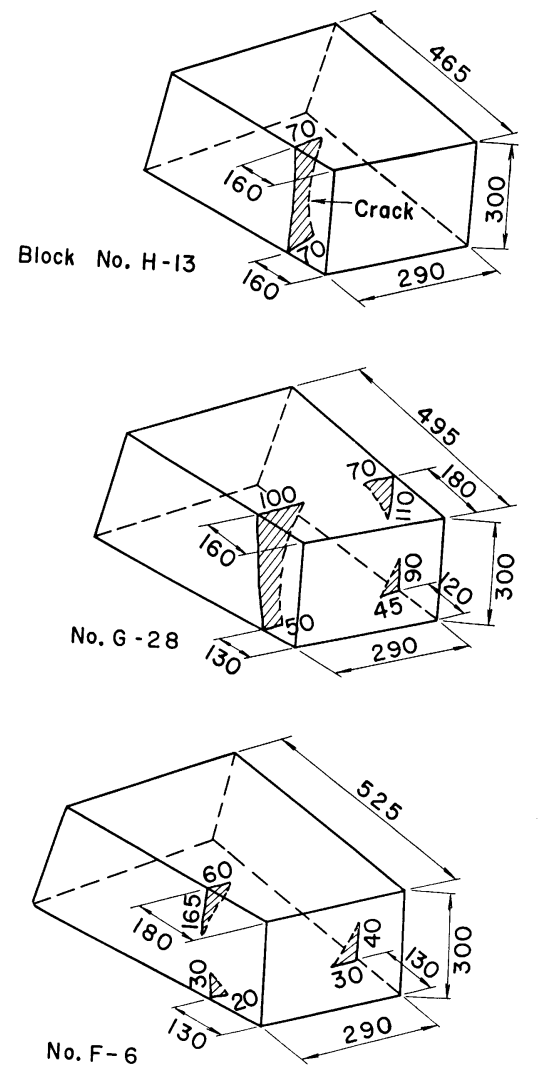

Fig. 8. Typical cracks in carbon blocks.
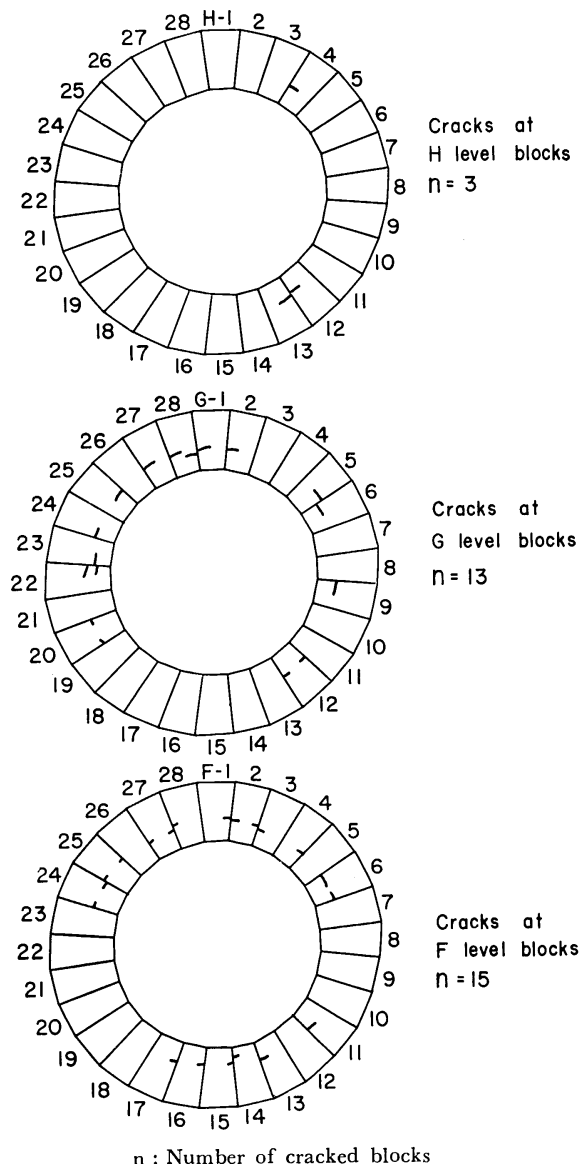

Fig. 9. Grack distribution at ring wall.

を調査した，その際に，湯溜り部カーボンブロック，炉 底シャモットれんがのいずれにも割れが発見された。

\section{$4 \cdot 1$ 湯溜り部カーボンブロックの割れ}

湯溜り部 F， G，H 段のカーボンブロックには, Fig. 8 に示すような割れが多数認められた. 各段の割れ発生 情況を Fig. 9 に示す. Fig. 9 に示すように F, G 段 では約半数のカーボンブロックに割れが見受けられた. これらの割れの特徵をまとめると次のよらになる.

(1) 割れはカーボンブロックの稼動面側から約 150 $\mathrm{mm}$ の位置において, 稼動面とほぼ平行に入つていた。

（2）割れはすべてカーボンブロック表面から発生 し, 切断後の目視検查では内部割れは認められなかつ た.

(3) Fig. 10 に示すように, 割れ発生点近傍より稼 動面側で, 最大 $1.1 \mathrm{~mm}$ の圧縮残留変形が周方向に生じ ていた.この変形量は，約 $0.4 \%$ の圧縮ひずみに相当す る. 


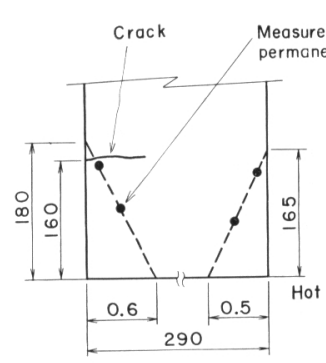

(a) $\mathrm{H}-\mathrm{I3}$

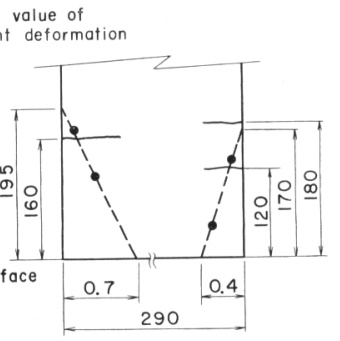

(b) $G-28$
Fig. 10. Relation between location of cracks and residual deformation in carbon blocks.
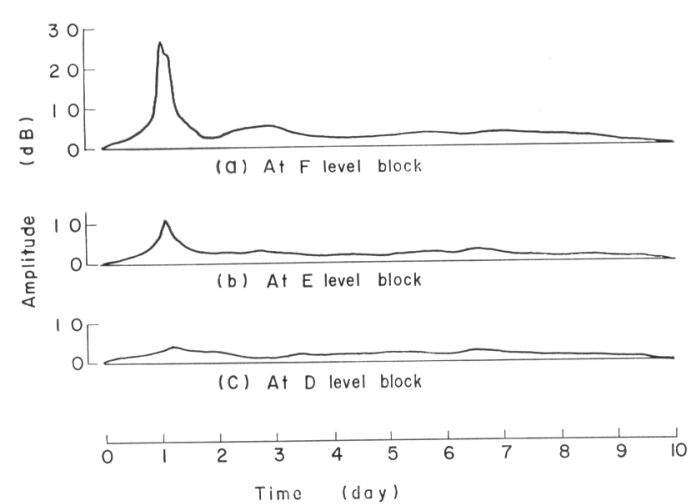

Fig. 11. Variation of amplitude of acoustic emission wave in carbon blocks.

(4) Fig. 11 に示す, AE 波測定記録より，割れの 発生時期は, 昇温開始後約 $24 \mathrm{~h}$ と考光られる.

ここで，この湯溜り部カーボンブロックの割れについ て検討する. 応力, 変形測定あるいは ( 3 )の残留変形か らは, カーボンブロックの熱膨張が鉄皮によつて拘束さ れ, カーボンブロックには周方向の圧縮応力が作用して いることがわかる.

多孔質脆性材料の圧縮荷重下の割孔は，高炉耐火物に 関する宮本ら ${ }^{10}$ ) 実験, あるいはコンクリートに関する W ITTMAN ${ }^{11)}$ のモデル解析に示されるように，ミクロク ラックが負荷方向に成長, 合体を続けることによつて生 ずる形態, あるいは, Photo. 1 に示すような, 巨視的 なせん断破壊状の形態になるのが一般的と考兄られる。 なお，耐火物のような脆性材料に秥ける割れは，GRIFFITH の破壞条件12) で示されているように, ミクロ的には 分離破壊によつて生じ, せん断破壊は生じないものとさ れている.したがつて, 又かけ上すべり線方向に生じた 割れをせん断破壊と呼ぶことに問題があると考えて, こ こではせん断破壊状と呼ぶこととした.

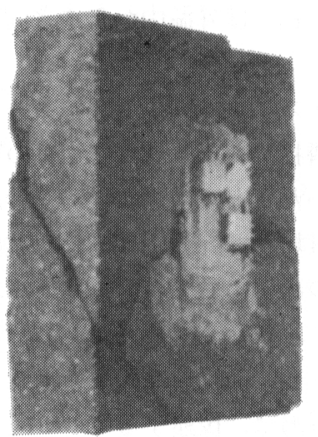

Photo. 1. Crack by compression.

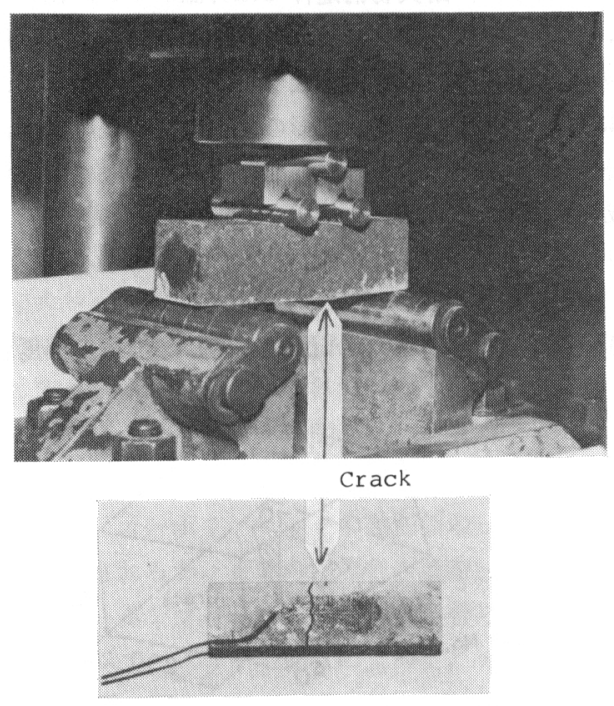

Photo. 2. Rupture test by bending.

本モデル炉実験のカーボンブロックの割れは, 周方向 に鋭い単一平面を形成している点に打いて, 上述の圧縮 下の割れとは異なり, Photo. 2 にお壮る曲げ試験, あ るいは, 割裂試験等で得られるよらな, 引張応力作用下 での割れ形態に近いと考光られる.

また，本実験に打けるカーボンブロックの割れ発生位 置 (稼動面から約 $150 \mathrm{~mm}$ の側面) に引張応力が発生す

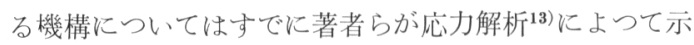
した。

\section{$4 \cdot 2$ 炉底シャモットれんがの割れ}

Fig. 1 に示すD段のシャモットれんがの稼動面（上 面）側では, Photo. 3 に示すような割れが発生してい た。この割れは, 目地数が少なく, したがつて熱膨張吸 収代が少ないれんが長手方向からの压縮によつて生じた せん断破壊状の割れであり，Photo. 1 亿近い形態と考 兄られる。 

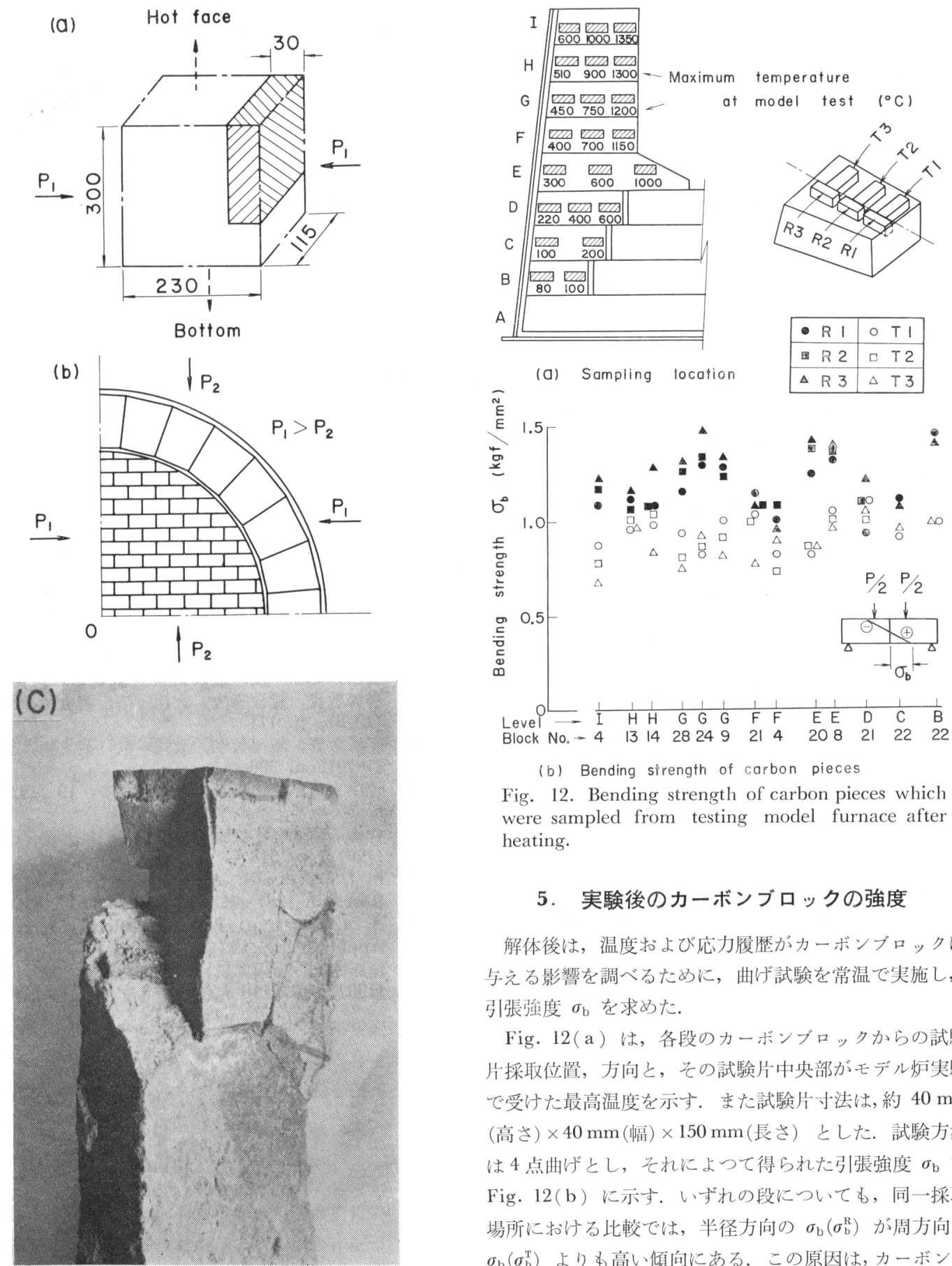

Fig. 12. Bending strength of carbon pieces which were sampled from testing model furnace after heating.

\section{5. 実験後のカーボンブロックの強度}

解体後は，温度和よび応力履歴がカーボンブロックに 与える影響を調べるために，曲げ試験を常温で実施し， 引張強度 $\sigma_{\mathrm{b}}$ を求めた。

Fig. 12(a) は，各段のカーボンブロックからの試験 片採取位置，方向と，その試験片中央部がモデル炉実験

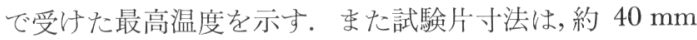
(高さ) $\times 40 \mathrm{~mm}$ (幅) $\times 150 \mathrm{~mm}$ (長さ) とした．試験方法 は4 点曲げとし, それによつて得られた引張強度 $\sigma_{\mathrm{b}}$ を Fig. 12(b) に示す. いずれの段についても, 同一採取 場所に打㤝る比較では, 半径方向の $\sigma_{\mathrm{b}}\left(\sigma_{\mathrm{b}}^{\mathrm{R}}\right)$ が周方向の $\sigma_{\mathrm{b}}\left(\sigma_{\mathrm{b}}^{\mathrm{T}}\right)$ よりも高い傾向にある. この原因は, カーボンブ ロックを押し出し成形する際に付加された，初期異方 性 ${ }^{10)}$ によると考光られる.

また，B，C，D段では, 試験片の半径方向採取位置の 差による $\sigma_{\mathrm{b}}$ の差が認められないが，E段よりも上部に 
ついては， $\sigma_{\mathrm{b}}^{\mathrm{T}}$ は稼動面側の方が鉄皮側より高く， $\sigma_{\mathrm{b}}^{\mathrm{R}}$ は 鉄皮側の方が稼動面側より高いといら傾向が 認められ る.

この現象は, 稼動面側が鉄皮側に比して温度が高かつ たこと，抗よび周方向圧縮力が大きかつたことに起因す るものと思われる.

\section{6. 結言}

高炉の炉底部構造を模擬したモデル炉によつて, 高炉 の火入れ時を想定した昇温実験, および昇降温繰り返し 実験を行つて，つぎの結論を得た。

（1）カーボンブロック，鉄皮の熱応力および熱変形 は, 最初の昇温時に大きな值を示し, その後の温度変動 時に打けるこれら諸量の変化は小さかつた. したがつて 高炉炉底部の耐火物の熱応力についても, 火入れ後の昇 温過程の評価が重要と考えられる.

（2）実験中のスタンプの変形挙動には不可逆性が観 察された。 また実験終了後の解体調査から, スタンプ・ 鉄皮間, スタンプ・カーボンブロック間および隣接カー ボンブロック間にすき間が観察された。 また，カーボン ブロックは昇温中に半径方向鉄皮側に移動する.この移 動によつて, 昇温中にもかかわらず, 隣接カーボンブロ ック間の鉄皮側にすき間が生じる可能性があることを理 論的に示した.

（3）炉底シャモットれんがの稼動面側では, 圧縮に より生じたと思われる, せん断破壊状の割れが観察され た.

（4）湯溜り部カーボンブロックの側面では，稼動面 から約 $150 \mathrm{~mm}$ の位置に, 稼動面と平行な割れが認めら れた.この割れは, AE 波測定結果より,昇温末期に生じ たことが推定された。 また, 温度測定結果によれば, こ の時の温度分布は定常状態のそれに近いものであつた.
（5）湯溜り部カーボンブロックの割れは, 丸棒ある いは直方体試験片に圧縮応力を作用させたときに現れる それとは異なり, 矩形断面梁の曲げ試験等において, 引 張縁から生じるような，鋭い平坦な平面を形成してい る.したがつて，モデル炉のカーボンブロックは，側面 に生じた引張応力に支配されたものと思われる.

（6）実験終了後の湯溜り部カーボンブロックから採 取した試験片による曲げ強度試験では, 周方向引張強度 は稼動面側の方が鉄皮側より高く，半径方向引張強度は 鉄皮側の方が稼動面側より高いといら傾向を示した.

おわりに，本モデル炉実験に多大な協力をいただいた 神戸製鋼所高知工場吉村厳氏, 岡本達夫氏をはじめ関係 諸氏に深く感謝いたします。

\section{交献}

1) 加瀬正司: 鉄と鋼, 68 (1982), p. 200

2) 熊谷正人, 内村良治, 川上辰男: 黨業協会誌, 87 (1981) 7, p. 356

3 ) 加藤一郎, 森田喜保, 桶上文範：鉄と鋼，68 (1982), p. 105

4 ) 飯山真人, 小山保二郎, 島田信郎, 板阊 隆：鉄 と鋼, 65 (1979), S 113

5 ) 熊谷正人, 内村良治, 吉川交明, 河合隆成：鉄と 鋼, 67 (1981), S 61

6 ）平櫛敬資, 大川 清, 桶渡幸夫, 萩原 武, 松本 義交, 藤原 茂：製鉄研究（1975）283，p. 110

7 ) 平櫛敬資, 桶渡幸夫, 大川 清: 耐火物, 30 (1978), p. 111

8 ) 平櫛敬資, 堀尾竹弘, 大川 清: 耐火物, 31 (1979), p. 388

9 ）竹中幸彦，江川幸一：非破壊検查，19（1975）10 p. 509

10) 宮本 学, 尾上俊雄, 成田貴一: 鉄と鋼, 67 (1981), p. 313

11) F. H. Wittman: Advances in Fracture Research 1981 (ICF 5) Vol. 4, p. 1467

12) A. A. Griffith: Proc. 1st Intern. Congr. Appl. Mech. (1924), p. 55

13) 藤原昭文, 広中邦沉, 藤野真之: 鉄と鋼, 68 (1982), p. 2116 